\title{
My View on COVID-19 Pandemic
}

\section{Bhagvan Kommadi*}

Director, Product Engineering, Value Momentum, India

*Corresponding Author: Bhagvan Kommadi, Director, Product Engineering,

Value Momentum, India

In December 2019, the Covid-19 virus was found in Wuhan. Wuhan is the Hubei province capital city. It has a population of 11 million people. It is a hub for travelers connecting china biggest cities listed below:

- $\quad$ Beijing

- Zhengzhou

- Shiyan

- Yichang

- Nanjing

- Nanchang

- Changsha

- Chongqing

- Chengdu

- Jiujiang

- Shenzhen

- Guangzhou

- Hefei

- Shanghai

- Shangqiu

- Enshi

- Nanyang

- $\quad$ Anging.

The virus Incubation period ranges from 2 to 14 days. The covid-19 common incubation period is 5 days. On January 26, 2020, 5 million people moved from Wuhan before lockdown to different cities. The COVID-19 virus is related to wholesale seafood in $\mathrm{Wu}-$ han. The virus transmitted human to human during the outbreak. Wuhan city is the biggest port connecting Shanghai and Chongqing. Yangtze River flows across Wuhan and is used to transport food and other items.

The virus originated in Wuhan from pangolins or bats and spread through seafood. China has Belt and Road initiative referred to as "Silk Roads". Silk Road connects china to Tehran, Moscow,
Received: April 13, 2020

Published: June 11, 2020

(C) All rights are reserved by Bhagvan

Kommadi.
Istanbul, Rotterdam, Venice, Athens, Nairobi, Colombo, Kolkata, Kuala Lumpur, Jakarta, Hanoi, and Guangzhou. The virus outbreak started in Iran and next in Italy.

The U.S which has the largest number of cases had 759,493 travelers from China during December, January, and February. Now the affected patients are recovering. The table below shows the recovered and China remains at the top on April 11, 2020.

\begin{tabular}{|l|c|c|c|}
\hline \multicolumn{1}{|c|}{ Country } & Cases & Recovered & Deaths \\
\hline USA & 501615 & 29191 & 18177 \\
\hline Spain & 161852 & 59109 & 16353 \\
\hline Italy & 147577 & 30455 & 18849 \\
\hline France & 125931 & 25195 & 13215 \\
\hline Germany & 122171 & 53913 & 2736 \\
\hline China & 83004 & 77455 & 3343 \\
\hline UK & 74605 & 590 & 8974 \\
\hline Iran & 70029 & 41947 & 4357 \\
\hline South Korea & 10450 & 7117 & 211 \\
\hline
\end{tabular}

Regarding COVID-19 Vaccines, five of them are in clinical trials. Vitamin C intravenous high dose helps in treating early COVID-19. Arsenicum Album-30 was declared around march last week as preventive for COVID-19 disease by Indian Ayush Ministry. Rumors and fears were common during the lockdown in many countries. The idea is to have fact-checked information like White Coats COVID-19 Campaign. The campaign had fact-checked information for doctors from authorized information sources. WhiteCoats team has enhanced the coverage on COVID-19 with a blog. We are enhancing the knowledge base to have learning capabilities. Self-manageable knowledge base has capability to maintain a disease registry and the registry can be updated from various popular data sources such as Orphanet, John Hopkins, NORD, CDC, and WHO. The knowledge base maintains the disease information in the registry and checks the data sources for updates. The updates on diseases and disease info is persisted into the knowledge base. During the lockdown, 
the Indian government shared the Telemedicine guidelines related to the remote doctor support.

Alpha and beta coronavirus was present in few Wuhan affected citizens. Delta and gamma coronavirus was the dominant one in Wuhan and east Asia. Another variant was found in Europe. Delta and gamma is the mutant of the alpha and beta coronavirus. European Variant is the variant of the Delta and Gamma Coronavirus. SARS-CoV and the Middle East respiratory syndrome-related (MERS) CoV are the parent virus for all the variants. COVID-19 has $79 \%$ similarity to the SARS-Corona Virus and $51.8 \%$ similarity to the MERS-Corona Virus, and 87.6 - 87.7\% similarity to ZC45 and ZXC21 variant of Corona Virus (SARS-like Corona Viruses from Chinese horseshoe bats) [1-3].

\section{Bibliography}

1. "Chinese Scientists Sequence Genome of COVID-19". Asian Scientist (2020).

2. Ranjit Sah., et al. "Complete Genome Sequence of a 2019 Novel Coronavirus (SARS-CoV-2) Strain Isolated in Nepal". Microbiology 9.11 (2020): e00169.

3. J Wang., et al. "Reasons for healthcare workers becoming infected with novel coronavirus disease 2019 (COVID-19) in China". Journal of Hospital Infection 105.1 (2020): 100-101.

\section{Assets from publication with us}

- Prompt Acknowledgement after receiving the article

- Thorough Double blinded peer review

- Rapid Publication

- Issue of Publication Certificate

- High visibility of your Published work

Website: www.actascientific.com/

Submit Article: www.actascientific.com/submission.php

Email us: editor@actascientific.com

Contact us: +919182824667 